\title{
Slovak Version of Internal and External Motivation to Respond without Prejudice Scale
}

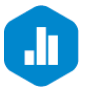

\author{
Drahomír Michalko ${ }^{1}$ (D) , Jana Plichtová ${ }^{2}$ \\ ${ }^{1}$ Department of Behavioral Neuroscience, Centre of Experimental Medicine, Slovak Academy of Sciences, Sienkiewiczo- \\ va 1,81371 Bratislava, Slovak Republic \\ ${ }^{2}$ Institute of Applied Psychology, Faculty of Social and Economic Sciences, Comenius University in Bratislava, Slovak \\ Republic
}

Internal and external motivation to respond without prejudice scale (IEMS) provides a self-report tool sensitive to individual tendencies to control implicit and explicit prejudice without directly inquiring about attitudes toward an outgroup. The current study verified the scale's psychometric properties and construct validity on a Slovak sample. In line with the predictions, the principal component analysis suggested, and confirmatory factor analysis validated the presence of two uncorrelated factors of internal and external motivation. Additionally, while internal motivation was positively associated with adherence to egalitarianism and negatively with authoritarianism, external motivation did not demonstrate any of these relationships. Furthermore, only external motivation was found to be positively related to expressive self-control that parallels propositions claiming greater self-regulatory demands when egalitarian norms are followed to avoid social disapproval. Finally, both factors were positively correlated with concerns from appearing prejudiced, although internal motivation in a significantly greater degree, reflecting larger dependency on self-oriented concerns. With appropriate values of internal consistency for both factors, the IEMS scale provides a reliable self-report measure that might be used for systematic control of individual differences in the research of social cognition in intergroup context.

Key words: prejudice, control of intergroup bias, self-report measure, psychometrics, construct validity

\section{Introduction}

Differentiation of high and low prejudiced persons became a central issue for social scien- tists studying intergroup relations. During the last decades, the insufficiency of traditional explicit self-report tools that inquire about personal intergroup attitudes grew more evident (Greenwald, McGhee, \& Schwartz, 1998;

Correspondence concerning this article should be addressed to Mgr. Drahomír Michalko, PhD., Department of Behavioral Neuroscience, Institute of Normal and Pathological Physiology, Centre of Experimental Medicine, Slovak Academy of Sciences, Sienkiewiczova 1, 81371 Bratislava, Slovak Republic. E-mail: drahomir.michalko@savba.sk Supplementary data for this paper are available at https://journals.savba.sk/index.php/studiapsychologica/article/ view/99

Received April 1, 2020

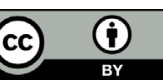


Payne, 2001, 2005). The reason is that this explicit inquiry about intergroup attitudes closely mirrors the prevalence of the old-fashioned form of racism, which predicts blatant expression of prejudice and stereotypes. However, with the introduction of progressive policies and legislative changes that promote egalitarian views and condemn prejudiced beliefs, newer forms of symbolic and aversive racism became pervasive in society (Pettigrew \& Merteens, 1995; Gaertner \& Dovidio, 1986). Contrary to old-fashioned racism, these forms predict implicit manifestation of prejudice and stereotypes reflected in implicit intergroup biases. These implicit biases represent habitual responses rooted in associative structures in both evaluative (negative emotional response - e.g., threat or disgust) and cognitive (reliance on stereotypes in the formation of social impression) domains. Crucially, as implied by their implicit nature, these habitual responses might be in direct opposition to explicit egalitarian attitudes toward an outgroup and hence do not depend on personal approval (Devine, 1989; Andersen, Moskowitz, Blair, \& Nosek, 2007; Strack \& Deutsch, 2004). Therefore, studying these implicit intergroup biases in high and low prejudiced persons required other means of differentiation than those that rely on the explicit inquiry into attitudes obscured by the need to fit with egalitarian norms.

Devine and Plant (1998) devised a self-report instrument that, contrary to traditional attitudinal questionnaires, does not directly inquire into intergroup attitudes, but rather into motivations of the person to respond without prejudice. This questionnaire, termed internal and external motivation to respond without prejudice scale (IEMS), is based on the premise that most of the variation, which we can observe in manifestations of intergroup bias, stems from the ability to effortfully overcome habitual responses operating on prejudiced associative structures (Devine, 1989; Brewer \& Feinstein, 1999; Fazio, 2007; Gawronski \& Bodenhausen, 2006). Consequently, at the same time, it assumes that we are, to a varying extent, under the constant influence of prejudiced automatisms by default. Further, this effortful override of implicit biases requires a deliberative engagement of cognitive control which, in a top-down manner, attenuates the influence of prejudiced associative structures (e.g., inhibits stereotypic associations and downregulates negative emotional reaction toward an outgroup) (Devine, 1989; Woodcock \& Monteith, 2009; Moskowitz, Gollwitzer, Wasel, \& Schaal, 1999; Woodcock \& Monteith, 2010; Bartholow, 2010; Cunningham et al., 2004; Payne, 2005). According to Devine and Plant (1998), this deliberative process of the control of prejudice is determined by the degree of a person's adherence to egalitarian values that can be motivated by two distinct sources. Specifically, people might control their biases because of internal and external reasons (motivations). Internal motivation (IM) incorporates egalitarian values into a personal value-system, which means that IM persons follow egalitarian norms to satisfy their standards. On the other hand, externally motivated (EM) persons follow egalitarian norms to conform to politically correct standards and to avoid social disapproval resulting from their violation. Thus, in IM persons, egalitarian values serve as an internal cue that guides the regulation of initial bias towards non-prejudiced expression. Differently, in EM persons, egalitarian values pose as an external cue that triggers the control of prejudiced bias depending on whether a social environment warrants the upholding of egalitarian norms. Then, although not previously reported, it is believed that high EM persons engage in expressive self-control to avoid a display of prejudiced attitudes (Plant \& Devine, 1998). Importantly, a person might be simultaneous- 
ly motivated by internal and external reasons, i.e. although there is some internalization of egalitarianism, a person might still perceive it's upholding as social pressure. This suggests that IM and EM are uncorrelated constructs.

Consequently, this discrepancy between IM and EM persons in the endorsement of egalitarian values leads to different outcomes regarding the intergroup contexts. First, compared to IM persons who can readily access egalitarian norms by repeated exercise, EM persons have greater difficulties utilizing these cues and thus are not as effective in the control of implicit bias. In particular, higher IM predicts lower bias on both explicit and implicit measures of intergroup bias (such as implicit association test, stereotype priming protocols, or startle-eyeblink paradigm) regardless of social settings, i.e. whether the social environment requires conformity with egalitarianism or not (Moskowitz, Gollwitzer, Wasel, \& Schaal, 1999). Conversely, EM does not significantly contribute to the reduction of implicit bias and responses to explicit measures of prejudice are skewed toward non-prejudiced answers when provided in public versus private settings (Plant \& Devine, 1998; Ryan \& Connel, 1989; Amodio et al., 2008; Amodio, Harmon-Jones, \& Devine, 2003; Devine et al., 2002). Interestingly, the research shows that high IM persons with high EM also do not exhibit a significant reduction of implicit bias (Amodio, Harmon-Jones, \& Devine, 2003). Secondly, IM and EM persons produce different patterns of emotional response when facing a violation of egalitarian norms. Specifically, failure to meet personal egalitarian standards by high IM persons might be accompanied by feelings of guilt and self-disappointment. As high EM persons conform to egalitarian norms to avoid social disapproval, their inability to withhold prejudiced expressions is, on the other hand, associated with experiencing a threat- or fear-related emotions
(Plant \& Devine, 1998; Higgins, 1987; Littleford, Wright, \& Sayoc-Parial, 2005; Monteith \& Mark, 2006; Amodio, 2009; Rankin \& Campbell, 1955; Stephan, 2014; Trawalter, Adam, Chase-Lansdale, \& Richeson, 2012). Thus, as shown by previous research, the IEMS shows a reasonable level of reliability in predicting intergroup bias and explaining inconsistencies between explicit and implicit measures of prejudice.

\section{Present Research}

Although the scale was originally developed to account for individual differences in intergroup bias against Blacks, it was adapted to evaluate internal and external motivations to withhold prejudice toward other minorities or marginalized social groups as well (Klonis, Plant, \& Devine, 2005; Pruett, Deiches, Pfaller, Moser, \& Chan, 2014). However, its psychometric properties have not been tested on population samples outside the United States, which is substantially different from regions of middle/eastern Europe in terms of cultural and historical experience with minorities. We believe that with the advance of egalitarian policies and norms in these cultural contexts, it is critical to establish this measure that would allow systematic control of individual differences in future research of intergroup relations. Therefore, following the seminal paper of Devine and Plant (1998), we assessed the psychometric properties and validity of the IEMS on a Slovak sample.

First, we tested the factor structure of the scale. Note, that despite the two-factor structure of the scale being well documented, it has not yet been estimated on a sample with the current socio-cultural background. Thus, before conducting a validating confirmatory factor analysis, we included an exploratory principal component analysis using an independent sample. Additionally, each sample 
rated the scale's items pertaining to different outgroups to test the instrument's robustness against variability in socio-cultural relevance. The two samples rated their motivation toward Blacks and Roma, respectively. We expected the IEMS items to load on two orthogonal factors resembling the constructs of internal and external motivation to respond without prejudice.

Subsequently, we examined whether these constructs match their main assumptions. Perhaps the most obvious distinction between these two constructs is the endorsement of egalitarian values. Differently from EM persons, who do not personally subscribe to egalitarianism, IM persons should demonstrate a greater inclination toward an internalized sense of equality concerning human rights. Concurrently, this internalized egalitarianism should be paralleled by the condemnation of authoritative values of hostility toward an outgroup. Therefore, we used the humanitarianism-egalitarianism and right-wing authoritarianism scales to assess their relationship with IM and EM, respectively. We anticipated IM to be positively related to humanitarianism-egalitarianism and negatively to right-wing authoritarianism. We did not expect to find significant correlations with these scales in the case of EM. Next, appearing prejudiced gives rise to different negative emotional outcomes in IM and EM persons. While IM persons experience self-anger caused by a distorted self-image, EM persons' emotional reactions point outward in the form of a perceived threat from potential social sanctions. Therefore, we expected that both IM and EM would be positively associated with concerns of appearing prejudiced. Further, one of the suspected reasons why EM persons might lapse in the control of implicit bias is that their executive capacities are being drained by self-regulatory processes involved in expressive self-control that prevents disclosure of prejudiced attitudes. For this reason, we expected that only the EM would be positively correlated with expressive self-control. Finally, as the IEMS does not probe into personal intergroup attitudes, both constructs should be independent of the need to comply with socially desirable answers. Hence, we did not hypothesize about any significant correlations of both constructs with the social desirability scale.

\section{Method}

\section{Participants}

The sample consisted of 484 university students (348 females) of average age 21.42 $(S D=2.54)$ from various backgrounds of study fields (IT, psychology, medicine, biology, and economy). The statistical analysis section provides additional information regarding the respective samples serving for PCA and CFA.

\section{Data Collection and Translation of the Scale}

The scales were administered to university student groups at social networks via online questionnaires (each form restricted to one submission per email address). The order of the questionnaires was randomly reshuffled for each participant. Note that PCA sample received only the IEMS. Data collection was conducted in two steps. First, we administered the IEMS with the outgroup of Roma together with the rest of the scales (this sample served for the later CFA analysis). In the second step, IEMS was administered as part of the recruitment for an upcoming experiment. In this phase, participants rated IEMS toward Blacks (PCA). Three independent translators (non-native speakers of English) translated the IEMS. The first two translators independently translated the IEMS items into the Slovak language. After the two trans- 
lators agreed on the Slovak wording of the IEMS items, the third translator translated the items back to English. The final edits of the Slovak translation (Appendix) were then made by all three translators.

\section{Self-Report Measures}

Note that none of the administered scales (except Social Desirability Scale) were standardized for the Slovak population. However, for each scale, we conducted separate PCAs that confirmed their structural properties (i.e., being saturated by one component). Moreover, their validity was supposed to be partially reflected in the predicted correlations with IEMS.

Internal and External Motivation to Respond without Prejudice Scale. In IEMS, the participant rates his/her agreement with ten statements (five for each factor) regarding his/her motivations to avoid prejudiced thoughts and behaviors towards an outgroup member in day-to-day life. The self-reporting is provided on a 9-point Likert scale (strongly disagree - strongly agree).

Humanitarianism and Egalitarianism Scale. Humanitarianism and Egalitarianism Scale is a 10-item inventory that measures tendency or adherence toward social justice, concerns for other's well-being, or democratic ideals of equality (Katz \& Hass, 1988). Internal consistency of the scale (estimated on the CFA sample) reached a satisfactory level, $\omega_{t}=.89$, $\alpha_{\text {ord }}=.89$.

Right-Wing Authoritarianism Scale. We used RWA (Saunders \& Ngo, 2017) to evaluate individual tendencies to express authoritatively sanctioned aggression toward outgroups. It contains ten items rated on a 9-point Likert scale (very strongly disagree - very strongly agree) with neutral middle-point. Estimates of internal consistency reached an acceptable level, $\omega_{t}=.75, \alpha_{\text {ord }}=.73$.
Concern from Appearing Prejudiced. This is a subscale of the MCP scale (Motivation to Control Prejudice) (Dunton \& Fazio, 1997). It assesses proneness to experiencing guilt or increased negative arousal as a consequence of appearing prejudiced. Eight items are rated on a 7-point Likert scale (strongly disagree strongly agree). Internal consistency for the subscale was appropriate, $\omega_{t}=.81, \alpha_{\text {ord }}=.81$.

Expressive Self-Control. This subscale of the Self-Monitoring Scale (Snyder \& Grangestad, 1986 ) is aimed to measure the tendency to adjust one's expressions to fit current social expectancies despite authentic beliefs. The scale constitutes of six items to which the participant responds on a binary scale (true false). Values of internal consistency showed a boundary of acceptable levels in our sample, $\omega_{t}=.66, \alpha=.65$.

Social Desirability Scale (Crowne \& Marlowe, 1960). SD scale evaluates the inclination to seek social approval. Thirty-three items rated on a binary scale (true - untrue) reached an acceptable level in terms of internal consistency, $\omega_{t}=.73, \alpha=.72$.

\section{Statistical Analysis}

Principal Component Analysis. To determine the number of extracted components, we used Parallel analysis (PA) with the PCA method (Horn, 1965). Both PA and subsequent PCA for obtaining factor loadings were conducted on the Spearman correlation matrix since the data were ordered on a relatively wider ordinal scale. In PA, we calculated the 95th percentile of eigenvalues from 1000 randomly generated matrices that served for direct comparison with eigenvalues derived from the observed matrix. Observed-matrix's component eigenvalue had to surpass the 95th percentile eigenvalue of its randomly generated counterpart to be considered for extraction. In the following PCA, the ob- 
served correlation matrix was tested for the assumption of sampling adequacy and reducibility by Bartlett's test of sphericity and Keiser-Meyer-Olkin test (KMO), respectively. Due to the hypothesized orthogonality of internal and external motivation factors, components were rotated by the "Varimax" rotation method. A strict rule to retain only items with factor loadings $\lambda \geq .50$ was adopted. PA and PCA were conducted on a sample of $N=354$ (247 females) with a mean age of $20.9 \pm 1.5$ years. Analyses were performed with the 'psych' package in the R programming environment (Revelle, 2017).

Confirmatory Factor Analysis. Two separate factor solutions were tested. In the first model, all items were saturated by one factor. The second model was defined as suggested by PCA. Additionally, we tested the independence of the factors by fitting the third model, which was of the same structure as the second one, except for the allowed covariance between the factors. To estimate model parameters, we used diagonally weighted least squares (DWLS) as the estimation method (DiStefano \& Morgan, 2014; Li, 2016). Factor loading estimates were supplied with robust standard errors. Models' appropriateness was evaluated by chi-square statistic complemented by its ratio to degrees of freedom $(C M I N / D F<2)$, comparative fit index $(C F I \geq$ .95), Tucker-Lewis index ( $T L I \geq .95)$, root mean square error of approximation (RMSEA $\leq .05)$, and standardized root mean square residual (SRMR $\leq .08)$. Model comparisons were conducted using a scaled chi-square difference test (Satorra, 2000). CFA was conducted on a sample of $N=130$ (101 females) of average age $22.6 \pm 3.5$ years. We ran the analyses with the 〈lavaan` package in R (Rosseel, 2012).

Internal Consistency. All internal consistency indexes were estimated on the Spearman correlation matrix. To account for possible violation of tau-equivalency of the scale,
Cronbach's alpha $\left(\alpha_{\text {ord }}\right)$ (Gadermann, Guhn, \& Zumbo, 2012) was complemented by McDonald's omega total coefficient (Zinbarg, Revelle, Yovel, \& Li, 2005). Coefficients were calculated separately for both factors of the IEMS scale on the combined sample from PCA and CFA analyses. Calculations were performed with the 'psych' package.

Convergent and discriminant validity. The construct validity of the scale was tested by Pearson correlations. We entered the raw scores of the scales into the correlation analyses. Correlations were estimated on the same sample as CFA. Sample-size was found to be adequate to detect even weaker relationships $(r>.25$ ), given $1-b=.20$ and $\alpha=.05$ (twotailed significance).

\section{Results}

\section{Principal Component Analysis of the IEMS}

Two components were suggested for the extraction by PA (Figure 1 A). Bartlett's test of sphericity and KMO indicated appropriateness of data's reduction, $\chi^{2}(45)=237.40$, $p<.001, K M O=.821$. Four items loaded positively $\left(M_{\lambda}=.85\right)$ on the first component (Table 1 and Figure $1 \mathrm{~B}$ ). This component contained items such as "I attempt to act nonprejudiced toward Blacks because it's personally important to me" or "Being nonprejudiced toward Blacks is important to my self-concept" resembling the factor of internal motivation. Five items loaded positively $\left(M_{\lambda}=.70\right)$ on the second component. Items such as "I'm keeping negative feelings towards Blacks to myself to avoid negative reactions from others" and "I act nonprejudiced toward Blacks because of pressures from others" were most characteristic of this component, which was labelled as external motivation. One item loaded negatively on the second component. 
Table 1 Standardized loadings (structural matrix) of IEMS items after varimax rotation from $P C A$

\begin{tabular}{|c|c|c|c|}
\hline Item & $\mathrm{C} 1$ & $\mathrm{C} 2$ & $h^{2}$ \\
\hline $\begin{array}{l}\text { I1. Attempt to act nonprejudiced toward B because it's } \\
\text { personally important to me }\end{array}$ & .87 & -.06 & .76 \\
\hline $\begin{array}{l}\text { 12. Being nonprejudiced toward } B \text { is important to my self- } \\
\text { concept }\end{array}$ & .87 & -.01 & .75 \\
\hline $\begin{array}{l}\text { 14. I'm personally motivated by my beliefs not to be prejudiced } \\
\text { toward B }\end{array}$ & .85 & -.12 & .73 \\
\hline $\begin{array}{l}\text { 15. Because of my personal values/believe that using stereotypes } \\
\text { about B is wrong }\end{array}$ & .83 & -.07 & .70 \\
\hline $\begin{array}{l}\text { 13. According to my personal values, using stereotypes about B } \\
\text { is ok }\end{array}$ & .25 & -.53 & .34 \\
\hline $\begin{array}{l}\text { E3. Keeping negative feelings towards } B \text { to myself/avoid } \\
\text { negative reactions. }\end{array}$ & -.24 & .75 & .62 \\
\hline E4. Act nonprejudiced toward B because of pressure from others & .02 & .73 & .53 \\
\hline $\begin{array}{l}\text { E5. Attempt to appear nonprejudiced toward B/avoid } \\
\text { disapproval from others }\end{array}$ & -.30 & .71 & .59 \\
\hline $\begin{array}{l}\text { E1. If acted prejudiced against B/concerned that others would } \\
\text { be angry with me }\end{array}$ & .06 & 68 & .47 \\
\hline $\begin{array}{l}\text { E2. Because of today's political correctness standards/try to } \\
\text { appear nonprejudiced }\end{array}$ & .27 & .64 & .48 \\
\hline
\end{tabular}

Table 2 Fit indices for one- and two-factorial model in CFA

\begin{tabular}{lcccccccccc}
\hline Model & $\chi^{2}$ & $D F$ & $p$ & $C M I N / D F$ & $C F I$ & $T L I$ & $R M S E A$ & $S R M R$ & $\Delta \chi^{2}$ & $\Delta p$ \\
\hline 1-factor & 132.46 & 27 & $<.001$ & 4.91 & .775 & .700 & .174 & .158 & - & - \\
2-factor & 34.58 & 27 & .149 & 1.28 & .984 & .978 & .046 & .076 & 160.52 & $<.001$ \\
\hline
\end{tabular}

Note. Models do not include item 13.

\section{Confirmatory Factor Analysis of the IEMS}

The first one-factorial solution resulted in poor-fit to the data, $\chi^{2}=143.63, D F=35, p<$ $.001, C M I N / D F=4.10, C F I=.779, T L I=.716$, RMSEA = .155, SRMR = .149. The second two-factor orthogonal model, suggested by the PCA, yielded markedly better results, however some fit-indices still suggested a rather unsatisfactory fit to the data in terms of resid- ual variances, $\chi^{2}=49.28, D F=35, p=.055$, $C M I N / D F=1.41, C F I=.971, T L I=.962, R M S E A$ $=.056, S R M R=.084$. We noticed that item I3 (Table 1 ) loaded poorly onto the internal motivation factor $(\lambda=.243, p=.021)$. Running the calculations again without this item loading on the internal motivation did not improve one-factor model's fit to considerable level, however the second model now showed a good fit to the data that was marked as a significant improvement from the first one (Ta- 
ble 2). Factor loadings for the two-factor model are depicted in Figure $1 \mathrm{C}$. Finally, the third model with allowed correlation between the factors also resembled a good fit $\left(\chi^{2}=31.92\right.$, $D F=26, p=.196, C M I N / D F=1.23, C F I=.987$, $T L I=.983, R M S E A=.042, S R M R=.079)$, however, the correlation was not significant $(r=$ -.068, $p=.581$ ) and the model fit was not significantly better than the orthogonal alternative, $\Delta \chi^{2}=0.27, \Delta p=.600$.

\section{Internal Consistency of Internal and External Motivation Factors}

Item 13 from the internal motivation factor was not included in the estimations of inter- nal consistency coefficients. The internal motivation factor showed good value of internal consistency, $\omega_{t}=.89, \alpha_{\text {ord }}=.89$. For the external motivation factor, internal consistency coefficients were in range of an acceptable level, $\omega_{t}=.76, \alpha_{\text {ord }}=.76$.

\section{Convergent and Discriminant Validity of the IEMS}

Pearson correlations of internal and external motivation factors with other administered scales are listed in Table 3. Internal and external motivation factors were independent of each other. Furthermore, while the internal motivation exhibited a significant positive correla-

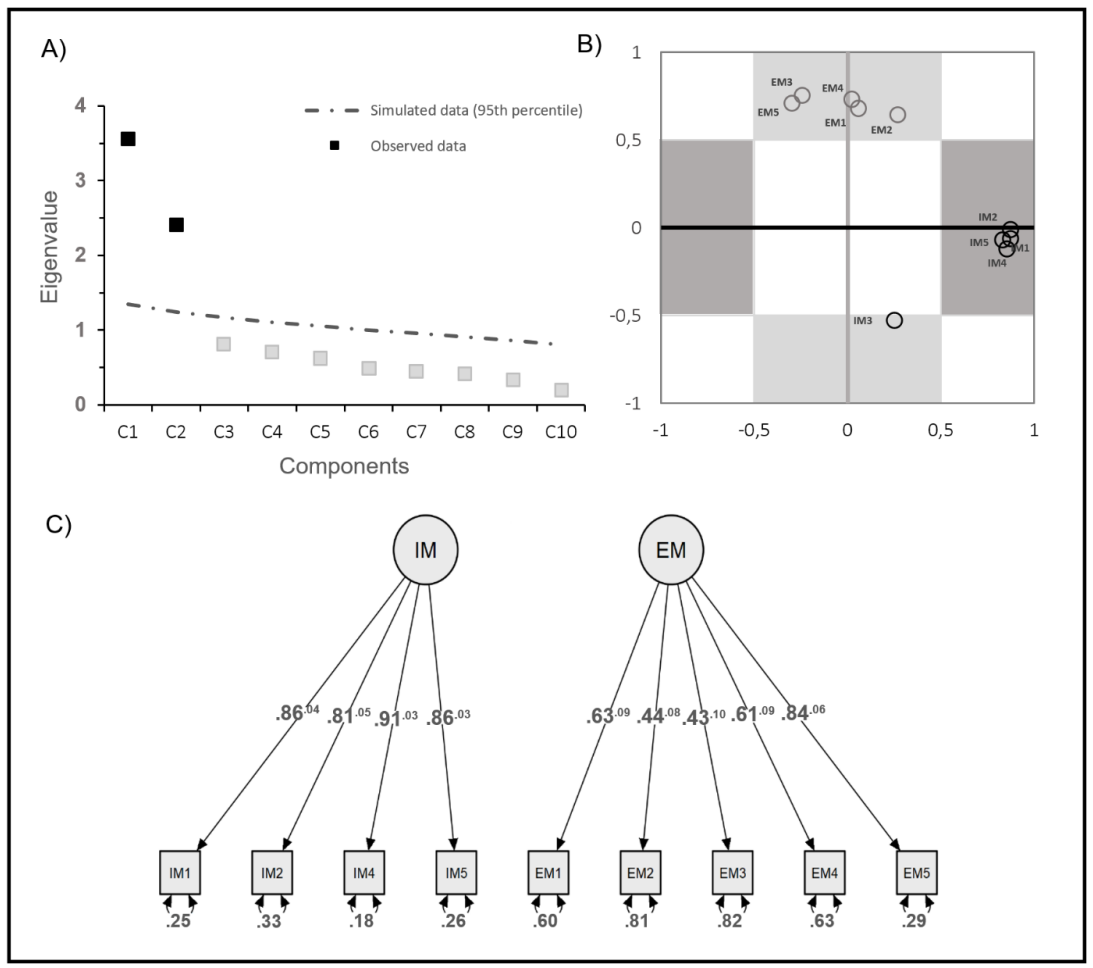

Figure 1 Results of PCA and CFA for IEMS. A) Scree-plot from the parallel analysis. B) IEMS items component loadings from PCA. C) Factor loadings with robust standard errors (upper index) and residual variances of the two-factorial model from CFA. IM - internal motivation. EM - external motivation. 
Table 3 Convergent and discriminant validity of IM and EM subscales (Pearson correlations)

\begin{tabular}{lll}
\hline Scale & IM & EM \\
\hline 1. Internal motivation to respond without prejudice & -- & -.04 \\
2. Humanitarianism \& Egalitarianism & $.49^{* * *}$ & .13 \\
3. Right-wing authoritarianism & $-.30^{* *}$ & .13 \\
4. Concerns from appearing prejudiced & $.51^{* * *}$ & $.25^{* *}$ \\
5. Expressive self-control & -.02 & $.23^{* *}$ \\
6. Social desirability & $.19^{*}$ & -.12 \\
\hline
\end{tabular}

Note. IM - Internal motivation, EM - External motivation.

${ }^{*} p<.050 ;{ }^{* *} p<.010 ; * * *<.001$

tion with humanitarianism-egalitarianism and negative correlation with RWA, the external motivation did not correlate with these scales. Both IEMS factors showed a positive correlation with concerns from appearing prejudiced. However, this correlation was considerably stronger for internal motivation compared to external motivation, with this difference being marked as significant, $Z=2.45, p=.014$. On the other hand, only the external motivation factor was positively and significantly associated with expressive self-control. Finally, internal motivation was marginally but significantly positively associated with social desirability. External motivation was not significantly associated with social desirability.

\section{Discussion}

The current study verified psychometric properties of internal and external motivation to respond without prejudice scale to establish a reliable measure upon which new studies concerned with intergroup behavior in the Slovak context could build their research designs.

Our results have robustly replicated the psychometric qualities of the IEMS scale (Plant \& Devine, 1998; Klonis, Plant, \& Devine, 2005; Pruett et al., 2014). Specifically, in both PCA and CFA, and across both social groups against which motivations to avoid prejudice were rated, we consistently observed that IEMS items clustered into two meaningful factors resembling two uncorrelated constructs reflecting internal and external reasons to avoid prejudiced thoughts and behaviors. Noteworthy, although not of much theoretical relevance regarding the examined constructs, one item ("According to my personal values, using stereotypes about Blacks is okay.") that was supposed to load on the internal motivation factor did not. Instead, it loaded negatively on the external motivation factor. One could argue that using this item for the assessment of external motivation would be plausible as it loaded extensively but negatively on this factor. However, this could prove misleading since an absence of internal reasons to avoid prejudice is not equal to the presence of external ones, as these constructs are independent of each other. Nevertheless, the removal of this item did not decrease the instrument's measurement properties, as even the fouritem internal motivation factor reached very acceptable values of internal consistency. External motivation factor, on the other hand, yielded somewhat weaker internal consistency that was, however, still within the safe range that would be considered for use in the research context.

Likewise, the constructs of internal and external motivation demonstrated their con- 
vergent and discriminant validity. First, only internalmotivation was positively related to humanitarianism-egalitarianism, suggesting that personal reasons to avoid prejudice are predominantly based in a deeper and more internalized sense of unity of humankind and adherence to values of equality concerning rights and opportunities for everybody. External motivation, on the other hand, yielded only a marginal positive trend with humanitarianism-egalitarianism. This might suggest that externally motivated persons might, to some extent, personally subscribe to egalitarianism but despite that, a huge portion of this adherence is more likely to be a result of compliance with social norms rather than their internalization. The positive association of internal motivation with humanitarianism-egalitarianism was paralleled by a negative association with RWA, mirroring the findings of Plant and Devine (1998). Interestingly, external motivation demonstrated a similar trend with RWA as towards humanitarianism-egalitarianism, suggesting again that externally motivated persons could also possess values that might be involved in social exclusion rather than inclusion. However, these correlations should be considered only in terms of speculations, since they were reported previously as insignificant even in larger samples (Plant \& Devine, 1998). We also identified a negative and significant correlation between external motivation and expressive self-control, which is in line with the assumption claiming that EM persons might alter their overt but also less apparent expressions of attitudes depending on whether their social environment is sensitive and punishing towards non-compliance with egalitarian norms. This result indirectly supports the notion that executive capacities required for control of intergroup bias might become consumed by self-regulation in externally motivated individuals. In contrast, the absence of a relationship between expres- sive self-control and internal motivation to respond without prejudice coincides with the idea that by chronic utilization of egalitarian cues, IM persons do not engage in self-control to a considerable degree (Plant \& Devine, 1998; Amodio, Harmon-Jones, \& Devine, 2003).

Next, we observed that internal motivation is more strongly related to concerns from appearing prejudiced than external motivation. A straightforward explanation of this pattern is that most of the items in the concerns from appearing prejudiced subscale address self-oriented concerns rather than those stemming from possible social rejection or sanctions. Yet, these results might have more serious consequences for intergroup contexts. Although negative emotional arousal or intergroup anxiety is associated principally with social threat related to external motivation in the intergroup context, the internal motivation also predicts heightened arousal during the intergroup settings that might produce uncertainties about personal egalitarian standards (Higgins, 1987; Littleford, Wright, \& Sayoc-Parial, 2005; Amodio, 2009; Rankin \& Campbell, 1955; Stephan, 2014; Trawalter, Adam, Chase-Lansdale, \& Richeson, 2012). Indeed, research of intergroup anxiety fairly neglects this aspect of internal motivation. Considering the adverse effects of intergroup anxiety on intergroup behavior as well as on neurocognitive systems subserving activation and control of intergroup bias, it would be beneficiary to reflect on the possibility that high internal motivation might also lead to heightened negative arousal as a consequence of deformed self-image and self-anger caused by not meeting personal standards (Higgins, 1987).

Finally, although to a marginal degree, internal motivation was significantly positively correlated with social desirability. This is somewhat unexpected as internal motiva- 
tion predicts adherence to egalitarianism to meet personal standards and not as a means by which to seek social approval. It might be speculated that a portion of some of the responses to internal motivation items might have been affected by the need to protect and maintain vulnerable self-esteem (e.g., Evans, 1979). Nevertheless, careful control for this variable should be considered when assessing internal motivation in individuals.

\section{Limitations of the Present Research}

There are two main limitations of this study. First, the size of the CFA sample was somewhat modest, and hence its statistical power, with regards to the utilized estimation method, could be severely limited for potential rejection of the model (Bandalos, 2014). Therefore, although our CFA model was relatively small, we recommend testing the model on a larger sample. Relatedly, both PCA and CFA samples were notably imbalanced in terms of gender. We are not aware of any theoretically plausible reasons to suspect gender-related differences in responding to IEMS. However, we suggest complementing the current findings with a direct test of measurement invariance. Finally, with regards to the validity of the scale, we did not include any measures of intergroup bias (explicit or implicit) and thus cannot make any conclusions regarding the predictive capabilities of the scale. Future studies should experimentally investigate whether the IM and EM subscales predict the outcomes on both explicit and implicit measures of prejudice.

\section{Summary}

In conclusion, the present investigation renders a solid starting point for establishing a self-report tool that can be reliably used for the differentiation of high and low prejudiced persons in the Slovak context.

\section{Acknowledgement}

This research was funded by the grant support APVV 17-0536 "Social representations of dementia and their implications for the support of cognitive health in Slovakia".

\section{Authors' ORCIDs}

Drahomír Michalko

https://orcid.org/0000-0001-7403-915X

Jana Plichtová

https://orcid.org/0000-0003-0835-8309

\section{References}

Amodio, D. M. (2009). Intergroup anxiety effects on the control of racial stereotypes: A psychoneuroendocrine analysis. Journal of Experimental Social Psychology, 45(1), 60-67. https://doi. org/10.1016/i.jesp.2008.08.009

Amodio, D. M., Devine, P. G., \& Harmon-Jones, E. (2008). Individual differences in the regulation of intergroup bias: The role of conflict monitoring and neural signals for control. Journal of Personality and Social Psychology, 94(1), 60-74. https://doi.org/10.1037/0022-3514.94.1.60

Amodio, D. M., Harmon-Jones, E., \& Devine, P. G. (2003). Individual differences in the activation and control of affective race bias as assessed by Startle Eyeblink Response and Self-Report. Journal of Personality and Social Psychology, 84(4), 738-753. https://doi.org/10.1037/0022$\underline{3514.84 .4 .738}$

Amodio, D. M., Harmon-Jones, E., Devine, P. G., Curtin, J. J., Hartley, L., Covert, A. E., \& Hartley, S. L. (2004). Neural signals for the detection of unintentional race bias. Psychological Science, 15(2), 88-93. https://doi.org/10.1111/i.09637214.2004.01502003.x

Andersen, S. M., Moskowitz, G. B., Blair, I. V., \& Nosek, B. A. (2007). Automatic thought. In A. W. Kruglanski \& E. T. Higgins (Eds.), Social psychology: Handbook of basic principles (pp. 138-176). New York, NY, US: The Guilford Press

Bartholow, B. D. (2010). On the role of conflict and control in social cognition: Event-related brain potential investigations. Psychophysiology, 
47(2), 201-212. https://doi.org/10.1111/i.14698986.2009.00955.x

Bandalos, D. L. (2014). Relative performance of categorical diagonally weighted least squares and robust maximum likelihood estimation. Structural Equation Modeling: A Multidisciplinary Journal, 21, 102-116. https://doi.org/10.1080/1070 5511.2014.859510

Brewer, M. B., \& Feinstein, A. S. H. (1999). Dual processes in the cognitive representation of person and social categories. In S. Chaiken \& Z. Trope (Eds.), Dual-process theories in social psychology (pp. 255-270). New York: Guilford Press.

Butz, D. A., \& Plant, E. A. (2009). Prejudice control and interracial relations: The role of motivation to respond without prejudice. Journal of Personality, 77(5), 1311-1341. https://doi. org/10.1111/j.1467-6494.2009.00583.x

Crosby, F., Bromley, S., \& Saxe, L. (1980). Recent unobtrusive studies of black and white discrimination and prejudice. Psychological Bulletin, 87, 546-563. https://doi.org/10.1037/0033-2909.87.3.546

Crowne, D. P., \& Marlowe, D. (1960). A new scale of social desirability independent of psychopathology. Journal of Consulting Psychology, 24(4), 349-354. https://doi.org/10.1037/h0047358

Cunningham, W. A., Johnson, M. K., Raye, C. L., Gatenby, J. C., Gore, J. C., \& Banaji, M. R. (2004). Separable neural components in the processing of black and white faces. Psychological Science, 15(12), 806-813. https://doi.org/10.1111/i.09567976.2004.00760.x

Devine, P. G. (1989). Stereotypes and prejudice: Their automatic and controlled components. Journal of Personality and Social Psychology, 56, 5-18. http://dx.doi.org/10.1037/0022-3514.56.1.5

Devine, P. G., Plant, E. A., Amodio, D. M., Harmon-Jones, E., \& Vance, S. L. (2002). The regulation of explicit and implicit race bias: The role of motivations to respond without prejudice. Journal of Personality and Social Psychology, 82(5), 835848. https://doi.org/10.1037/0022-3514.82.5.835

DiStefano, C., \& Morgan, G. B. (2014). A comparison of diagonal weighted least squares robust estimation techniques for ordinal data. Structural Equation Modeling, 21(3), 425-438. https:// doi.org/10.1080/10705511.2014.915373

Dunton, B. C., \& Fazio, R. H. (1997). An individual difference measure of motivation to control prejudiced reactions. Personality and Social Psychology Bulletin, 23(3), 316-326. https://doi. org/10.1177/0146167297233009

Evans, R. G. (1979). The relationship of the Marlowe-Crowne Scale and its components to defensive preferences. Journal of Personality Assessment, 43(4), 406-410. https://doi.org/10.1207/ s15327752jpa4304 13

Fazio, R. H. (2007). Attitudes as object evaluation associations of varying strength. Social Cognition, 25(5), 603-637. https://doi.org/10.1521/ soco.2007.25.5.603

Forbes, C. E., Cox, C. L., Schmader, T., \& Ryan, L. (2012). Negative stereotype activation alters interaction between neural correlates of arousal, inhibition and cognitive control. Social Cognitive and Affective Neuroscience, 7(7), 771-781. https://doi.org/10.1093/scan/nsr052

Gadermann, A. M., Guhn, M., \& Zumbo, B. D. (2012). Estimating ordinal reliability for Likerttype and ordinal item response data: A conceptual, empirical, and practical guide. Practical Assessment, Research and Evaluation, 17(3), 1-13.

Gaertner, S. L., \& Dovidio, J. F. (1986). The aversive form of racism. In J. F. Dovidio \& S. L. Gaertner (Eds.), Prejudice, discrimination and racism. New York: Academic Press.

Gawronski, B., \& Bodenhausen, G. V. (2006). Associative and propositional processes in evaluation: An integrative review of implicit and explicit attitude change. Psychological Bulletin, 132(5), 692-731. https://doi.org/10.1037/00332909.132.5.692

Greenwald, A. G., McGhee, D. E., \& Schwartz, J. L. K. (1998). Measuring individual differences in implicit cognition: The implicit association test. Journal of Personality and Social Psychology, 74(6), 1464-1480. https://doi.org/10.1037/00223514.74.6.1464

Higgins, E. T. (1987). Self-discrepancy: A theory relating self and affect. Psychological Review, 94(3), 319-340. http://dx.doi.org/10.1037/0033$\underline{\text { 295X.94.3.319 }}$

Horn, J. (1965). Factors in factor analysis. Psychometrika, 30(2), 179-185.

Katz, I., \& Hass, R. G. (1988). Racial ambivalence and American value conflict: Correlational and priming studies of dual cognitive structures. Journal of Personality and Social Psychology, 55(6), 893-905. 
Klonis, S. G., Plant, E. A., \& Devine, P. G. (2005). Internal and external motivation to respond without sexism. Personality and Social Psychology Bulletin, 31(9), 12371249. https://doi.org/10.1177/0146167205275304

Li, C. H. (2016). Confirmatory factor analysis with ordinal data: Comparing robust maximum likelihood and diagonally weighted least squares. Behavior Research Methods, 48(3), 936-949. https://doi.org/10.3758/s13428-015-0619-7

Littleford, L. G., Wright, M. O., \& Sayoc-Parial, M. (2005). White students' intergroup anxiety during same-race and interracial interactions: A multimethod approach. Basic and Applied Social Psychology, 27(1), 85-94. https://doi. org/10.1207/s15324834basp2701 9

Monteith, M. J., \& Mark, A. Y. (2006). Changing one's prejudice ways: Awareness, affect, and self-regulation. European Review of Social Psychology, 16(1), 113-154. https://doi. org/10.1080/10463280500229882

Moskowitz, G. B., Gollwitzer, P. M., Wasel, W., \& Schaal, B. (1999). Preconscious control of stereotype activation through chronic egalitarian goals. Journal of Personality and Social Psychology, 77(1), 167-184. https://doi.org/10.1037/00223514.77.1.167

Payne, B. K. (2001). Prejudice and perception: The role of automatic and controlled processes in misperceiving a weapon. Journal of Personality and Social Psychology, 81(2), 181-192. https:// doi.org/10.1037//0022-3514.81.2.181

Payne, B. K. (2005). Conceptualizing control in social cognition: How executive functioning modulates the expression of automatic stereotyping. Journal of Personality and Social Psychology, 89(4), 488-503. https://doi.org/10.1037/0022$\underline{3514.89 .4 .488}$

Pettigrew, T. F., \& Meertens, R. W. (1995). Subtle and blatant prejudice in western Europe. European Journal of Social Psychology, 25(1), 57-75. https://doi.org/10.1002/ejsp.2420250106

Plant, E. A., \& Devine, P. G. (1998). Internal and external motivation to respond without prejudice. Journal of Personality and Social Psychology, 75(3), 811-832. http://dx.doi.org/10.1037/0022 3514.75.3.811

Pruett, S. R., Deiches, J., Pfaller, J., Moser, E., \& Chan, F. (2014). A psychometric validation of the Internal and External Motivation to Re- spond without Prejudice toward People with Disabilities Scale. Rehabilitation Research, Policy, and Education, 28(1), 24-32. https://doi. org/10.1891/2168-6653.28.1.24

Rankin, R. E., \& Campbell, D. T. (1955). Galvanic skin response to Negro and white experimenters. Journal of Abnormal and Social Psychology, 51(1), 30-33. https://doi.org/10.1037/h0041539 Revelle, W. (2017). psych: Procedures for Personality and Psychological Research. Northwestern University, Evanston, Illinois, USA. https://CRAN. Rproject. org/package $=$ psych Version $=1.7 .8$

Rosseel, Y. (2012). lavaan: An R package for Structural Equation Modeling. Journal of Statistical Software, 48(2), 1-36. https://doi.org/10.18637/ jss.v048.i02

Ryan, R. M., \& Connel, J. P. (1989). Perceived locus of causality and internalization: Examining reasons for acting in two domains. Journal of Personality and Social Psychology, 57(5), 749-761. http://dx.doi.org/10.1037/0022-3514.57.5.749

Satorra, A. (2000). Scaled and adjusted restricted tests in multi-sample analysis of moment structures. In R. D. H. Heijmans, D. S. G. Pollock, \& A. Satorra (Eds.), Innovations in multivariate statistical analysis. A Festschrift for Heinz Neudecker (pp. 233-247). London: Kluwer Academic Publishers.

Saunders, B. A., \& Ngo, J. (2017). The Right-Wing Authoritarianism Scale. In V. Zeigler-Hill \& T. K. Shackelford (Eds.), Encyclopedia of Personality and Individual Differences (pp. 1-4). https://doi. org/10.1007/978-3-319-28099-8 1262-1

Sigall, H., \& Page, R. (1971). Current stereotypes: A little fading, a little faking. Journal of Personality and Social Psychology, 18(2), 247-255. https:// doi.org/10.1037/h0030839

Snyder, M., \& Grangestad, S. (1986). On the nature of self-monitoring: Matters of assessment, matters of validity. Journal of Personality and Social Psychology, 51(1), 125-139. Retrieved from http://psycnet.apa.org/journals/psp/51/1/125/

Stephan, W. G. (2014). Intergroup anxiety: Theory, research, and practice. Personality and Social Psychology Review, 18(3), 239-255. https://doi. org/10.1177/1088868314530518

Strack, F., \& Deutsch, R. (2004). Reflexive and impulsive determinants of social behaviour. Per- 
sonality and Social Psychology Review, 8(3), 220-247. https://doi.org/10.1207/s15327957pspr0803 1

Trawalter, S., Adam, E. K., Chase-Lansdale, P. L., \& Richeson, J. A. (2012). Concerns about appearing prejudiced get under the skin: Stress responses to interracial contact in the moment and across time. Journal of Experimental Social Psychology, 48(3), 682-693. https://doi.org/10.1016/i. jesp.2011.12.003

Woodcock, A., \& Monteith, M. J. (2009). Reducing implicit bias through the self-regulation of prej- udiced responses. Paper presented at the Midwestern Psychological Association.

Woodcock, A., \& Monteith, M. J. (2010). Creating a common ingroup to combat implicit bias. $\mathrm{Pa}$ per presented at the Midwestern Psychological Association.

Zinbarg, R. E., Revelle, W., Yovel, I., \& Li, W. (2005). Cronbach's $\alpha$, Revelle's $B$, and McDonald's $\omega_{H}$ : Their relations with each other and two alternative conceptualizations of reliability. Psychometrika, 70(1), 123-133. https://doi. org/10.1007/s11336-003-0974-7

\section{Appendix}

Internal and external motivation to respond without prejudice scale in Slovak language

$$
\text { Item }
$$

1. Osobne mi záleží na tom, aby som voči Rómom nemal predsudky.

2. Z hl'adiska môjho seba-ponímania je pre mňa dôležité, aby som neprejavoval voči Rómom predsudky.

3. Keby som vyjadril(a) predsudky voči Rómom, obával(a) by som sa, že sa na mňa môžu ostatní hnevat'.

4. Stereotypné zmýšl’anie o Rómoch neprotirečí mojim hodnotám.

5. Štandardy politickej korektnosti ma vedú k tomu, aby som voči Rómom neprejavoval predsudky.

6. Svoj negatívny pohlad na Rómov si nechávam radšej pre seba, aby som sa vyhol negatívnym reakciám druhých.

7. Moje presvedčenia a hodnoty ma osobne motivujú, aby som voči Rómom nemal predsudky.

8. Kvôli tlaku zo strany spoločnosti sa pokúšam správat' voči Rómom nepredsudočne.

9. Moje osobné hodnoty mi nedovolia, aby som prejavoval voči Rómom predsudky.

10. Aby som sa vyhol nesúhlasu ostatných, snažím sa robit' dojem, že voči Rómom nemám žiadne predsudky.

Note. Items are rated on 9-point Likert scale (strongly disagree - strongly agree). Item 4 has reversed scoring. Items written in bold pertain to internal motivation subscale. 